\title{
A Mineralogical Museum as a Geotourism Attraction: A Case Study
}

\author{
Magner Turner-Carrión ${ }^{1}$, Paúl Carrión-Mero ${ }^{2,3, * \mathbb{D}}$, Israel Turner-Salamea ${ }^{1}$, Fernando Morante-Carballo ${ }^{4}$, \\ Maribel Aguilar-Aguilar ${ }^{2, *}$, Kerly Zambrano-Ruiz ${ }^{5}$ and Edgar Berrezueta ${ }^{6}$ (D)
}

1 Museo Mineralógico Magner Turner, Portovelo 071150, Ecuador; magnerturnersavage@yahoo.com (M.T.-C.); turnerlovemetall@hotmail.com (I.T.-S.)

2 Centro de Investigaciones y Proyectos Aplicados a las Ciencias de la Tierra (CIPAT), Escuela Superior Politécnica del Litoral, ESPOL Polytechnic University, Campus Gustavo Galindo Km 30.5 Vía Perimetral, Guayaquil 9015863, Ecuador

3 Facultad de Ingeniería en Ciencias de la Tierra, Escuela Superior Politécnica del Litoral, ESPOL Polytechnic University, Campus Gustavo Galindo Km 30.5 Vía Perimetral, Guayaquil 9015863, Ecuador

4 Facultad de Ciencias Naturales y Matemáticas, Geo-recursos y Aplicaciones GIGA, Escuela Superior Politécnica del Litoral, ESPOL Polytechnic University, Campus Gustavo Galindo Km 30.5 Vía Perimetral, Guayaquil 9015863, Ecuador; fmorante@espol.edu.ec

5 Independent Consultor, Zaruma 071350, Ecuador; kgzambra@espol.edu.ec

6 Departamento de Infraestructura Geocientífica y Servicios, Instituto Geológico y Minero de España (IGME, CSIC), 33005 Oviedo, Spain; e.berrezueta@igme.es

check for updates

Citation: Turner-Carrión, M.; Carrión-Mero, P.; Turner-Salamea, I.; Morante-Carballo, F.; Aguilar-Aguilar, M.; Zambrano-Ruiz, K.; Berrezueta, E. A Mineralogical Museum as a Geotourism Attraction: A Case Study. Minerals 2021, 11, 582. https:// doi.org/10.3390/min11060582

Academic Editors: João Pedro Veiga, Mathilda Larsson Coutinho and Elin Figueiredo

Received: 4 May 2021

Accepted: 26 May 2021

Published: 30 May 2021

Publisher's Note: MDPI stays neutral with regard to jurisdictional claims in published maps and institutional affiliations.

Copyright: (c) 2021 by the authors. Licensee MDPI, Basel, Switzerland. This article is an open access article distributed under the terms and conditions of the Creative Commons Attribution (CC BY) license (https:/ / creativecommons.org/licenses/by/ $4.0 /)$.
* Correspondence: pcarrion@espol.edu.ec (P.C.-M.); maesagui@espol.edu.ec (M.A.-A.); Tel.: +593-99-826-5290 (P.C.-M.); +593-98-286-3190 (M.A.-A.)

Abstract: The Zaruma-Portovelo mining district in Ecuador, and in particular, Portovelo City, is home to the oldest mining museum in the country. This museum, named Museo Mineralógico Magner Turner (MMMT in Spanish), is a centre that reflects, through its collections, the history and culture of this territory. This work aimed to evaluate the MMMT as a possible geosite by analysing its contributions to the geomining heritage of the Zaruma-Portovelo district, and thus, to enhance it and promote its collections as a geotouristic attraction. The work involved three phases: (i) describing the museum and its surroundings; (ii) a semiquantitative evaluation of the museum using the Brilha method and a geosites assessment model (GAM); and (iii) a qualitative evaluation using the Delphi and SWOT methodologies to define strategies and proposals for museum development. The results obtained by the semiquantitative evaluation of the geosite with the Brilha method reflect high scientific (330/400), educational (380/400) and touristic $(365 / 400)$ appeal. The applied GAM shows the museum as a geosite with high principal and additional value, placing it in the $\mathrm{Z}_{33}$ field of the global valuation matrix. In addition, the semiquantitative and qualitative evaluation made it possible to describe the importance of the museum and its collections in the development of the area. The study carried out qualified the museum as a mining site with an appropriate valuation, an example of ex-situ geological heritage conservation and a basis for geotourism development.

Keywords: mineralogical museum; Portovelo; mining district; geomining heritage; geotourism

\section{Introduction}

Natural diversity is a concept that integrates biodiversity and geodiversity [1]. According to [2], geodiversity is the variability of Earth's surface materials, landforms and physical processes (abiotic elements). Geodiversity is also defined as the variety of geological elements which constitute the substrate of a region on which organic activity is based, including the anthropic [3]. The need to conserve geological elements with significant value is reflected in the study of geological heritage, whose discipline constitutes one of the most recent research areas within Earth sciences [4]. In recent years, several authors [1,2,5-11] have focused their research on the study of geological heritage. According to [1], geological 
heritage is a fundamental part of natural heritage and can be defined as the geodiversity elements (geosites) with unique value. There are different types of geological heritage, including mines, landforms, glaciers, ice-age phenomena and other geomorphological features $[11,12]$.

The term geotourism is related to geodiversity and geoheritage and has been defined by several authors [11,13-23]. Currently, the most internationally accepted definition is that of Newsome and Dowling [11]: "Geotourism is a form of natural area tourism that specifically focuses on geology and landscape. It promotes tourism to geosites and the conservation of geodiversity, and an understanding of earth sciences through appreciation and learning. This is achieved through independent visits to geological features, use of geotrails and viewpoints, guided tours, geoactivities, and patronage of geosite visitor centres".

Geosites are sites of geological interest with high scientific, educational and touristic value, representing the geological heritage of an area [24]. There are geosites at risk of natural or anthropic degradation (e.g., mines and roads) for which geoconservation is not always the most appropriate solution, and other conservation interventions are requires. For this, two categories of inanimate natural monuments must be distinguished: (i) immovable geological heritage (IGH) that cannot be removed from the surrounding environment, for which protection must be in-situ, and (ii) movable geological heritage $(\mathrm{MGH})$, which can be protected ex-situ within a museum. Within the MGH, minerals and fossils stand out that need to be protected and preserved ex-situ through their inclusion in museum collections $[10,25]$. One purpose of these institutions is to facilitate access and use of resources, promoting development for the benefit of society [26,27]. In addition to their scientific value, these collections have high cultural, historical and educational value, making it possible to publicise the importance of protecting the environment for the sake of such things [28,29].

At present, to protect geosites at high degradation risk whose geological heritage is IGH, constructions/rooms/museums have been built in the places where these are located. Some examples of these constructions are the Museum Hauff in Holzmaden (Germany); the Glacier Garden in Lucerne (Switzerland); the Geological Reserve of Haute-Provence (France) [30]; the dinosaur footprint site in La Rioja (Spain) [31]; The Muenchehagen Dinosaur Track (Alemania) [32]; the National Museum of Natural History of the University of Lisbon (Portugal) [33]; and El Sexmo Tourist Mine in Zaruma (Ecuador) [34]. In other cases, certain geological elements have been transported to museums or educational institutions far from their origins. Some examples of places which have exhibition rooms for geological, mineralogical, paleontological and other research pieces are the Museum of Natural Sciences of Madrid, where the largest meteorite that has fallen in Spain is preserved [4]; the Mining Museum of Argentina; the Mineralogical School of Mineral Science and Technology Museum in Ouro Preto-Brazil; and the Geology Museum of the National Autonomous University of Mexico (UNAM) [35]. Another example is the Geomining Museum (Instituto Geológico y Minero de España in Madrid), where thousands of samples of minerals, rocks, gems and fossils are exhibited [36].

In 2019, the AECOM (Architecture, Engineering, Consulting, Operations and Maintenance) and TEA (Themed Entertainment Association), in their Global Attractions Attendance Report, published the world's top of the most visited museums [37]. This report highlights the Natural History Museum in London and the American Museum of Natural History, as they include the world's most essential and comprehensive collections of mineral specimens.

In the context of Latin America, being a large and diverse region with a solid cultural identity [38], the Red-Pop (Network for the Popularisation of Science and Science) was created in 1990. Technology in Latin America and the Caribbean). This network has more than 80 members from 15 countries [39], whose purpose is to disseminate scientific and cultural issues through museums. In Ecuador, a country rich in tangible and intangible assets, national policies include protecting, restoring and disseminating assets [40] to protect and preserve the country's plurinational, multicultural and multiethnic identity. In 
Ecuador, museums are open to the public and have a broad vision in informative, scientific and cultural ways; they bring together geological history for society. Examples include, the Earth Sciences Museum of the Central University of Ecuador (UCE), the Natural History Museum of the National Polytechnic School (EPN) and the Paleontological Museum of the Santa Elena Peninsula University (UPSE). According to [41], the Ecuadorian museum must show society's historical, political and cultural processes. In the southwest of Ecuador, in Portovelo, there is the Museo Mineralógico Magner Turner (MMMT). This museum is the largest in the southern region of Ecuador, with approximately $400 \mathrm{~m}^{2}$ for the collection's exhibition, and it has an on-site mine for the tourists to visit [42]. The MMMT is considered a site of potential geological interest for the Ruta del Oro Geopark project. This project originated as an academic research project by ESPOL Polytechnic University; its initiative promotes the sector's economic development through geotourism [43].

This study aimed to evaluate the MMMT as a geosite that combines information about and experiences of geology and gold mining through semiquantitative (Brilha and GAM method) and qualitative (Delphi and SWOT) assessments. We thereby aim at promoting it as part of the geomining heritage of the Zaruma-Portovelo district. In addition, we aimed to determine the museum's influence on the development of geotourism in the area.

\section{Mineralogical Museum: MMMT}

\subsection{Geographical Setting}

The MMMT is located in southern Ecuador, in the El Oro province (Figure 1a,b), precisely placed in the Portovelo canton (Figure 1c,d) of Zaruma-Portovelo mining district. Geographically, the museum's territory is on the western slope of the Cordillera de los Andes (Cordillera Chilla) in the middle-upper section of the hydrographic basin Puyango River. Morphologically, the most notable characteristic is the mountainous relief, characterised by fluvial incisions with significant water flows [44-46]. The main characteristics of the terrain are irregular landscapes with steep slopes $\left(30^{\circ}-45^{\circ}\right)$ towards the NW and shallow slopes $\left(20^{\circ}-35^{\circ}\right)$ towards the SE [47]. There are V-shaped valleys and elevations between 600 and $1600 \mathrm{~m}$ above sea level [48]. In general, the study area presents a climate defined as semi-humid to humid, with approximate temperatures between 18 and $30{ }^{\circ} \mathrm{C}$ and average annual rainfall of $1300 \mathrm{~mm}$. Precipitation occurs in two rainy seasons (January to May and October to November) [47], conditioning the flow of water in the hydrographic system [49].

From the geological perspective, in the area (Portovelo and its surroundings), continental volcanic rocks, plutonic rocks and metamorphic rocks predominate. The predominant structures present an E-W alignment, which is discordant with the northern and eastern Andean system with a dominant NNE direction [46,50,51]. The gold mineralisation in the study area is part of an intermediate sulphidation vein system (Zaruma-Portovelo deposit) of $\mathrm{Au} \pm \mathrm{Ag} \pm \mathrm{Cu}$ [52]. This deposit has been related to propylitic, argillic, silica and sericitic types of alterations [53,54], and it is regionally located in the extension of the southwestern segment of the Miocene metallogenic belt in Ecuador [55]. The identified ore and gangue mineral assemblages are typical for intermediate sulfidation epithermal gold vein deposits associated with Early Miocene continental arc magmatism [54,56,57], among which there are three distinguishable mineralisation stages: quartz-pyrite, quartzpolymetallic and quartz-carbonate stages [53,57]. These vein systems have been established in three mineralised domains: N-S, NE-SW, and NW-SE [53]. The main hydrothermal alteration types are propylitic, argillic, silicic and sericitic assemblages. Gold mineralisation occurs in association with pyrite, chalcopyrite, sphalerite, galena, bornite, hematite, tetrahedrite, molybdenite and electrum. Quartz and calcite are the most important gangue minerals $[50,53]$. 

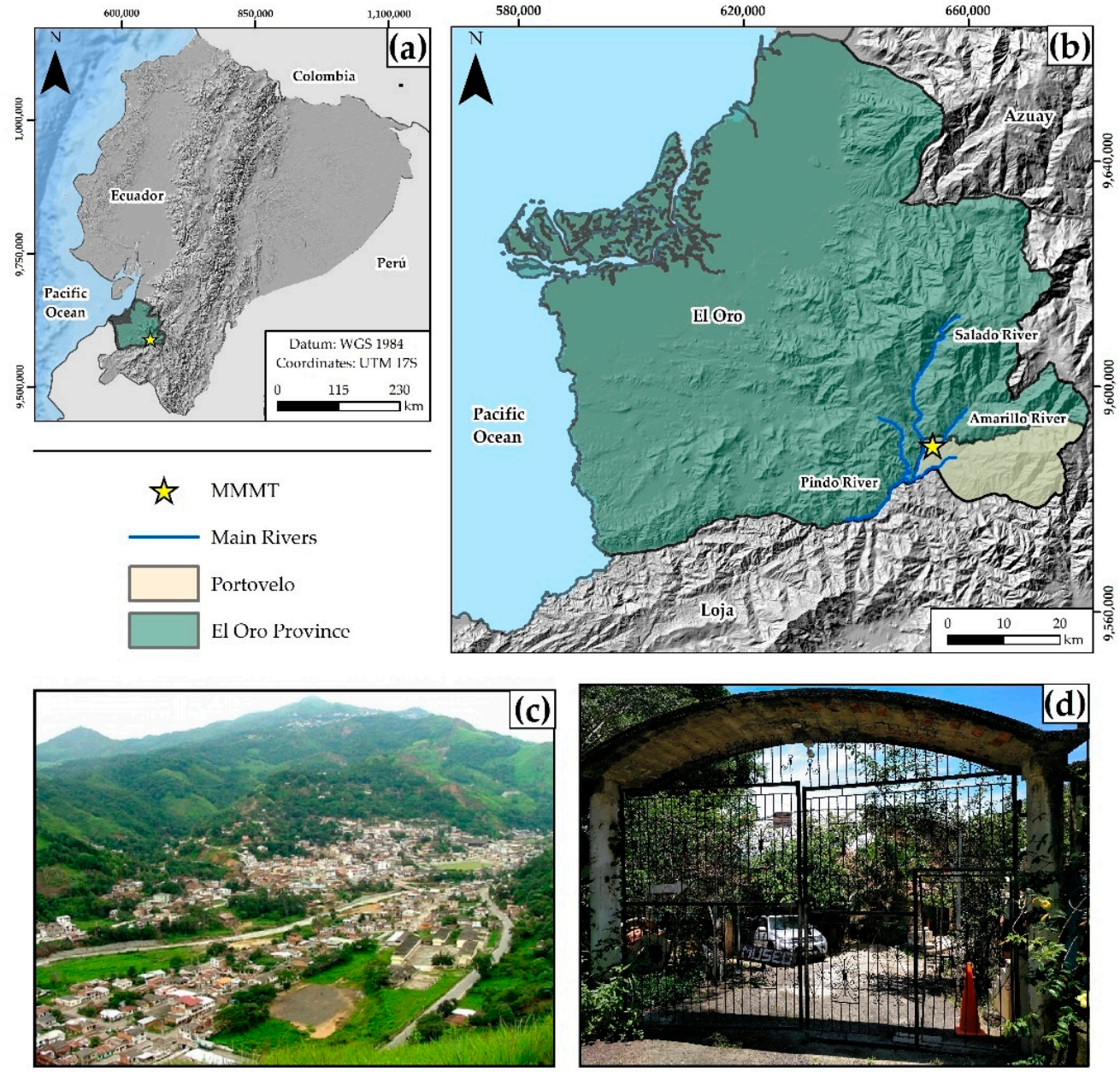

Figure 1. (a,b) Study area location. (c) Panoramic view of Portovelo city. (d) Museo Mineralógico Magner Turner.

The socioeconomic activity of the Portovelo region in particular, depends mainly on four axes: gold extraction (65\% of the economically active population), agriculture, livestock and tourism. In the last decade, national and international tourism have increased, and in turn the local economy has grown in response to tourism by means of businesses involved in culture, gastronomy, geology, mining history and archaeology. Portovelo city occupies an area of approximately $1 \mathrm{~km}^{2}$ and has 12,000 inhabitants [58].

\subsection{Specific Characteristics}

The main mine of the Zaruma-Portovelo mining district was developed by the American company South American Development Company (SADCO, New York, NY, USA), and used from 1896 to 1950 [53,59]. During the SADCO period, mineral extraction techniques were carried out with blasting using explosives. The mine started with a vertical tunnel (called Pique Americano in Spanish) $30 \mathrm{~m}$ in depth, and lateral tunnels were built; this method was used to reach 13 levels of depth. The company had a pulley system that allowed the ore from veins to be transported to the surface for processing. Grinding mills carried out the mineral processing, and the gold was obtained by amalgamation with mercury. The company also installed treatment plants for gold recovery by cyanidation processes [53,60-63].

As a result of the mining developed in the area and its importance at the national level, in 1976, Mr. Magner Turner started a private collection of 1500 mineral samples and mining equipment from the SADCO period. In the 80 s, the museum was strengthened with the acquisition of 3000 pieces catalogued in a very general way. The samples acquired 
are mainly crystallographic, speleological and paleontological. In the 90s, the samples reached 5000 pieces exhibited in an approximate area of $400 \mathrm{~m}^{2}$. In the last decade, the museum reached 7000 samples and the operation of three in-situ mines. Currently, the MMMT consists of 14 different sections/areas that exhibit national and international mineral collections, fossils and rocks, pieces, photos, objects and old equipment that reflect the mining activity of the district. Outside, the MMMT has three underground mines, which encourages visitors to interact with the galleries and a stone path known as SADCO Road, which contains a historical area typical for gold mining (Figure 2).

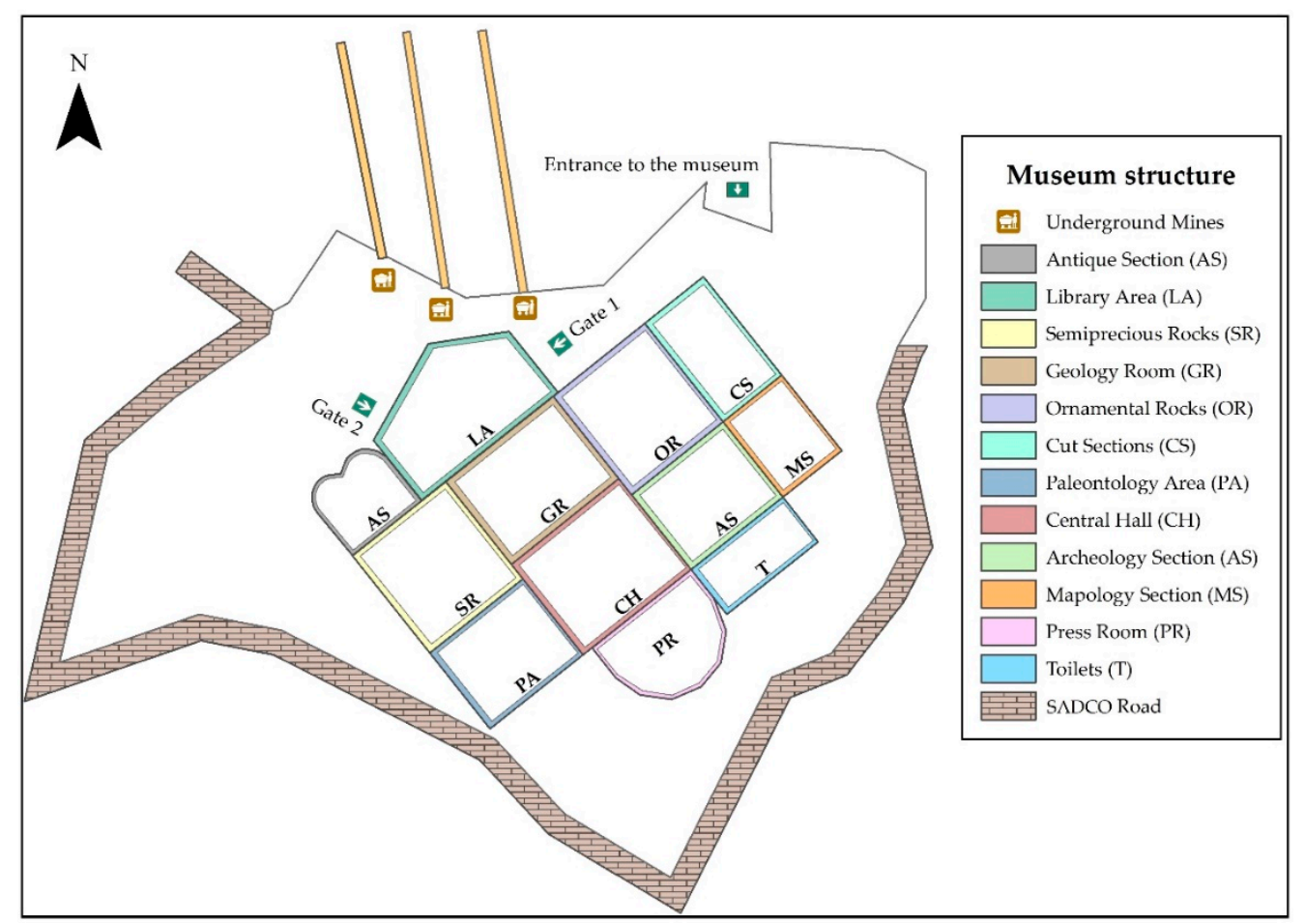

Figure 2. MMMT map with a description of the exhibition hall's structure, exhibition galleries and external routes.

Among the MMMT's main activities are visits to the in-situ mines made up of three galleries (Ray Turner Mine, Curipamba Mine and Ecuador Mine) with a total route length of $200 \mathrm{~m}$ (Figure S1). In the galleries, there are mineralogical samples (quartz drusen and pyrites), rocks (intrusive and host rock), tools and machinery and artefacts from the time of exploitation by SADCO. Inside the exhibition hall, there are approximately: 1500 samples of igneous, metamorphic and sedimentary rocks (Figure S2); 2500 mineralogical samples that are metallic and non-metallic (Figure S2); 550 precious and semi-precious stones (Figure S2); paleontological units (Figure S3); 50 caving units (Figure S3); 450 ancient pieces, including coins and artisanal mining equipment (Figure S4); and 700 archaeological pieces (Figure S4).

\section{Materials and Methods}

The analysis and evaluation process consisted of three phases (Figure 3): (i) taking a detailed inventory of the historical, cultural and touristic attractions, and analysing the infrastructure of the MMMT; (ii) an assessment of the interest and importance of the MMMT with two different evaluation methods; and (iii) defining strategies that optimise the use of the mine using Delphi analysis and strengths, weaknesses, opportunities and threats (SWOT) analysis (Figure 3). 

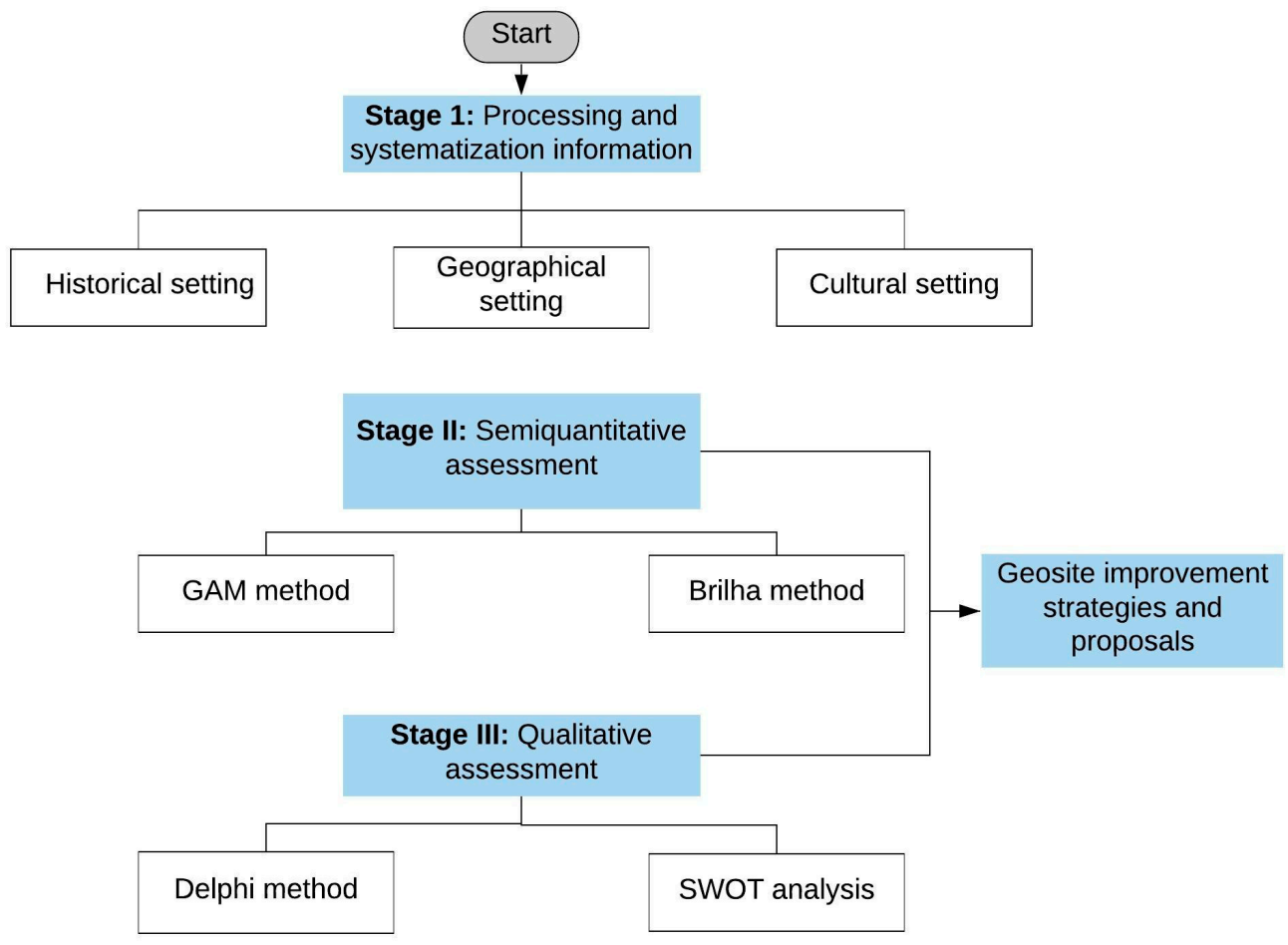

Figure 3. A flowchart of the methodology used in this study.

\subsection{Stage I: Processing and Systematisation Information}

The first stage comprised the analysis of cultural and historical information from the museum and the geographic environment of the area. In addition, this phase included recording the structure and services of the museum, including the collection types and the annual registry of visits. The processed information was the basis for the evaluation developed in phase two.

\subsection{Stage II: Semiquantitative Assessment}

A semiquantitative assessment was carried out within this phase using two methods, GAM [64] and Brilha [1]. Five academic experts assessed geology and geotourism with each of the selected methods. To do this, the evaluators used the information obtained in phase one. The final evaluation was the average of the values assigned by each evaluator. Finally, the compilation and summary of the assessments carried out (parameters and scores) allowed us to interpret the site.

\subsubsection{Geosite Assessment Model (GAM)}

A GAM is a method that evaluates the main and additional value of the geosite, making use of different indicators [64]. Each indicator establishes specific sub-indicators that are assessed from 0 to 1 (Table 1 ).

The sum of the values obtained for each subindicator placed the geosite in an analysis matrix of principal values from 0 (minimum) to 12 (maximum) vs. additional values from 0 (minimum) to 15 (maximum). The higher the values for the geosite, the higher the global value. This graphical representation type facilitates the interpretation of the current site state.

\subsubsection{Brilha Method}

The Brilha method evaluates geosites through four indicators: (i) scientific value (SV), (ii) potential educational use (PEU), (iii) potential touristic use (PTU) and (iv) degradation risk (DR) [1]. Each indicator analyses different sub-indicators scored from 1 (minimum) to 4 (maximum) and has a weight, as shown in Table 2. 
Table 1. The geosite assessment model (GAM) shows the main indicators of value and the indicators of additional value [64].

\begin{tabular}{|c|c|c|c|}
\hline \multicolumn{4}{|c|}{ Geosite Assessment Model (GAM) } \\
\hline \multicolumn{2}{|r|}{ Indicators/Subindicators } & \multicolumn{2}{|c|}{ Indicators/Subindicators } \\
\hline \multirow{6}{*}{$\begin{array}{l}\stackrel{\mathscr{E}}{\Xi} \\
\frac{\pi}{J} \\
\stackrel{\Xi}{\Sigma}\end{array}$} & Scientific/Educational Values (VSE) & \multirow{6}{*}{ 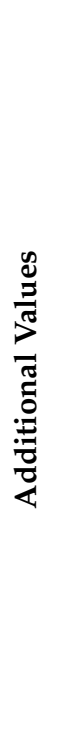 } & Functional Values (VFn) \\
\hline & $\begin{array}{l}\text { 1. Rarity } \\
\text { 2. Representativeness } \\
\text { 3. Knowledge on geoscientific issues } \\
\text { 4. Level of interpretation }\end{array}$ & & $\begin{array}{l}\text { 1. Accessibility } \\
\text { 2. Additional natural values } \\
\text { 3. Additional anthropogenic values } \\
\text { 4. Vicinity of emissive centres } \\
\text { 5. Vicinity of important road network } \\
\text { 6. Additional functional values }\end{array}$ \\
\hline & Scenic/Aesthetic Values (VSA) & & Touristic Values (VTr) \\
\hline & $\begin{array}{l}\text { 1. Viewpoints } \\
\text { 2. Surface } \\
\text { 3. Surrounding landscape and nature } \\
\text { 4. Environmental fitting of sites }\end{array}$ & & $\begin{array}{l}\text { 1. Promotion } \\
\text { 2. Organised visits } \\
\text { 3. Vicinity of visitor center } \\
\text { 4. Interpretative panels }\end{array}$ \\
\hline & Protection (VPr) & & 5. Number of visitors \\
\hline & $\begin{array}{l}\text { 1. Current condition } \\
\text { 2. Protection level } \\
\text { 3. Vulnerability } \\
\text { 4. Suitable number of visitors }\end{array}$ & & $\begin{array}{l}\text { 6. Tourism infrastructure } \\
\text { 7. Tour guide service } \\
\text { 8. Hostelry service } \\
\text { 9. Restaurant service }\end{array}$ \\
\hline
\end{tabular}

When evaluating the SV, PEU and PTU indicators, a high value has a positive connotation for the geosite. However, when assessing the DR indicators, high values represent negative connotations (risk) for the geosite.

Table 2. Criteria and indicators used for the quantitative assessment of geosites [1].

\begin{tabular}{|c|c|c|c|c|}
\hline \multicolumn{2}{|c|}{ Indicators/Subindicators } & \multirow{2}{*}{ Values } & \multirow{2}{*}{\multicolumn{2}{|c|}{ Weight }} \\
\hline \multicolumn{2}{|c|}{ Scientific Value (SV) } & & & \\
\hline \multicolumn{2}{|c|}{ Representativeness } & & \multicolumn{2}{|c|}{30} \\
\hline \multicolumn{2}{|c|}{ Key locality } & & \multicolumn{2}{|c|}{20} \\
\hline \multicolumn{2}{|c|}{ Scientific knowledge } & & \multicolumn{2}{|c|}{5} \\
\hline \multicolumn{2}{|c|}{ Integrity } & $1-4$ & \multicolumn{2}{|c|}{15} \\
\hline \multicolumn{2}{|c|}{ Geological diversity } & & \multicolumn{2}{|c|}{5} \\
\hline \multicolumn{2}{|c|}{ Rarity } & & \multicolumn{2}{|c|}{15} \\
\hline \multicolumn{2}{|c|}{ Use limitations } & & \multicolumn{2}{|c|}{10} \\
\hline \multicolumn{2}{|c|}{ (SV) Total } & & \multicolumn{2}{|c|}{100} \\
\hline \multicolumn{2}{|c|}{$\begin{array}{c}\text { Potential Educational Use (PEU) and Potential Tourism } \\
\text { Use (PTU) }\end{array}$} & Values & \multicolumn{2}{|c|}{ Weight } \\
\hline PEU & PTU & & PEU & PTU \\
\hline Vulnerability & & & 10 & 10 \\
\hline Accessibility & & & 10 & 10 \\
\hline Use limitations & & & 5 & 5 \\
\hline Safety & & & 10 & 10 \\
\hline Logistics & & & 5 & 5 \\
\hline Density of population & & & 5 & 5 \\
\hline Association with other val & & $1-4$ & 5 & 5 \\
\hline Scenary & & & 5 & 15 \\
\hline Uniqueness & & & 5 & 10 \\
\hline Observation conditions & & & 10 & 5 \\
\hline Didactic potential & Interpretative potential & & 20 & 10 \\
\hline Geological diversity & Economic level & & 10 & 5 \\
\hline & Proximity of recreational areas & & & 5 \\
\hline Total & & & 100 & 100 \\
\hline
\end{tabular}


Table 2. Cont.

\begin{tabular}{ccc}
\hline Degradation Risk (DR) & Values & Weight \\
\hline Deterioration of geological elements & & 35 \\
Proximity to areas/activities with potential to cause degradation & & 20 \\
Legal protection & $1-4$ & 20 \\
Accessibility & & 15 \\
Density of population & 10 \\
Total & 100 \\
\hline
\end{tabular}

The method proposes a DR classification based on the total value of the evaluation (Table 3), which establishes ranges for DR of low, medium and high.

Table 3. Degradation risk (DR) classification [1].

\begin{tabular}{cc}
\hline Total Weight & DR \\
\hline$<200$ & Low \\
$201-300$ & Moderate \\
$301-400$ & High \\
\hline
\end{tabular}

\subsection{Stage III: Qualitative Assessment}

The third stage was based on Delphi's geosite strategic analysis [65,66] and SWOT [67]. The Delphi method was the first analysis applied with the participation of five academic evaluators (stage two evaluators). The evaluation analysed three main aspects: (i) importance within the geological heritage of the area, (ii) services for tourists and (iii) natural and anthropic threats. This information can be used to describe its current potential and design improvements.

The main aspects of the Delphi method were the basis for the SWOT analysis. The SWOT analysis's objective was to determine the museum's potential for geotourism development in the area. We then wished to generate initiatives to make the use and management of the museum more efficient and effective. In addition to the academic evaluators' criteria, this phase of work will involve the participation of municipal authorities and the inhabitants of the area.

\section{Results}

\subsection{MMMT General Information}

The annual registry of MMMT's national and international visits shows a tourist influx of more than 4000 tourists in the last six years (2015-2020). The museum receives 700 tourists a year, with higher values in 2015, 2016 and 2017 than in 2018, 2019 and 2020 (Figure 4). The reasons for the visits' evolution are mainly (i) the problems derived from the land in-stabilities [68] and subsidence events in Zaruma city linked to illegal gold mining $[49,69,70]$, which caused a decrease in the tourist influx in the district in 2018 and 2019, and (ii) the global pandemic by COVID-19 in 2020.

According to the data provided by the MMMT, the maximum capacity per visit is 20 people. The organised groups that visit the MMMT are normally students from schools, colleges and universities. When the number of visits exceeds the capacity limit, the owner distributes the times into different time slots. The average duration of a visit is approximately two hours $(20 \mathrm{~min}$ for museum introduction and history, $50 \mathrm{~min}$ for viewing collections/exhibitions, $30 \mathrm{~min}$ for underground visits and $20 \mathrm{~min}$ for external exhibits of mining equipment). In addition to the guide's explanations, the MMMT has basic information (e.g., posters) to facilitate self-guided visits. As an urban museum, the visitor has within walking distance the necessary essential services (hotels and restaurants). 


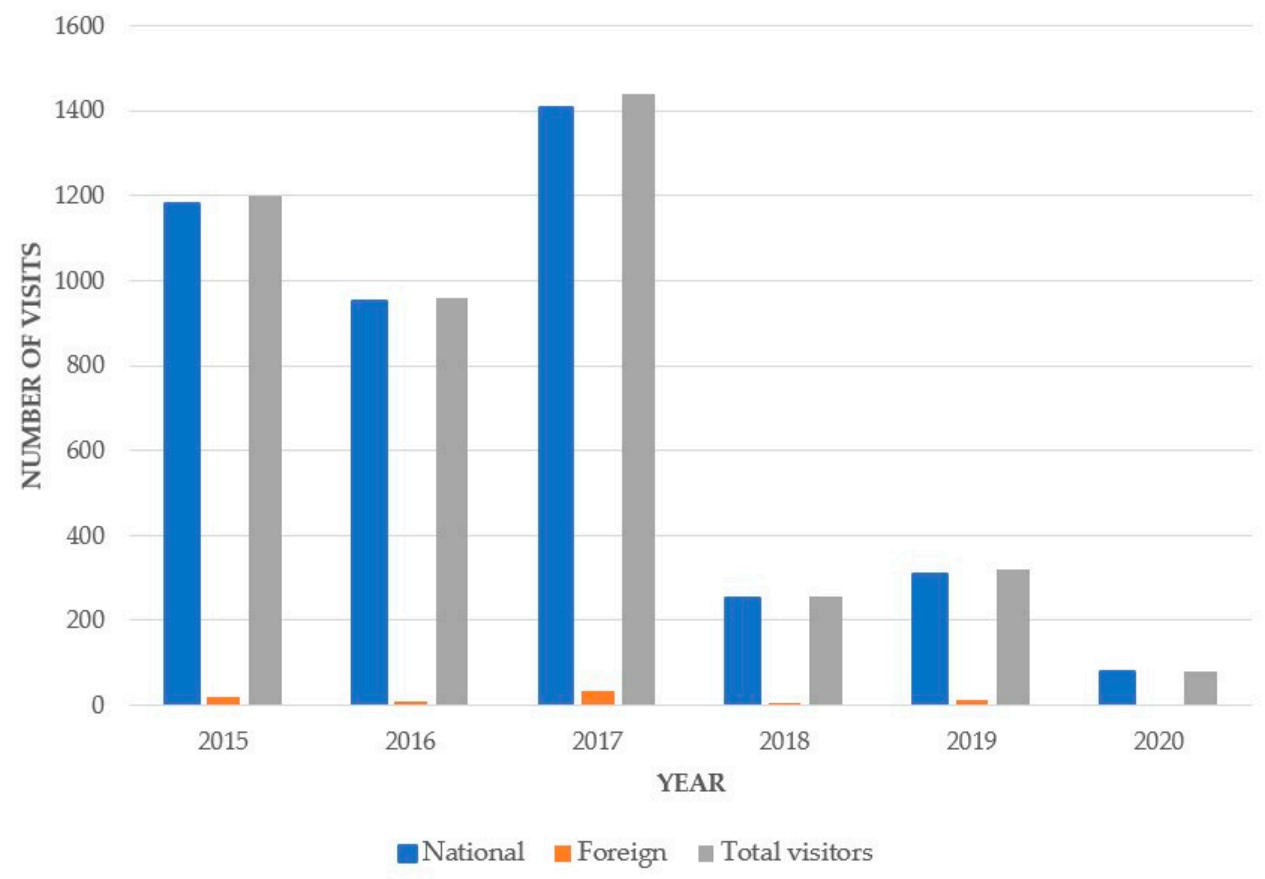

Figure 4. Annual visit data of the MMMT. Source: MMMT.

\subsection{Semiquantitative Assessment: GAM and Brilha}

The GAM assessment applied to the MMMT showed global ratings of 8.75/12 for main value and 12/15 for additional value (Table 4). The scores obtained locate the MMMT in the $\mathrm{Z}_{33}$ field of the GAM matrix (Figure 5), placing it as a geosite of high value.

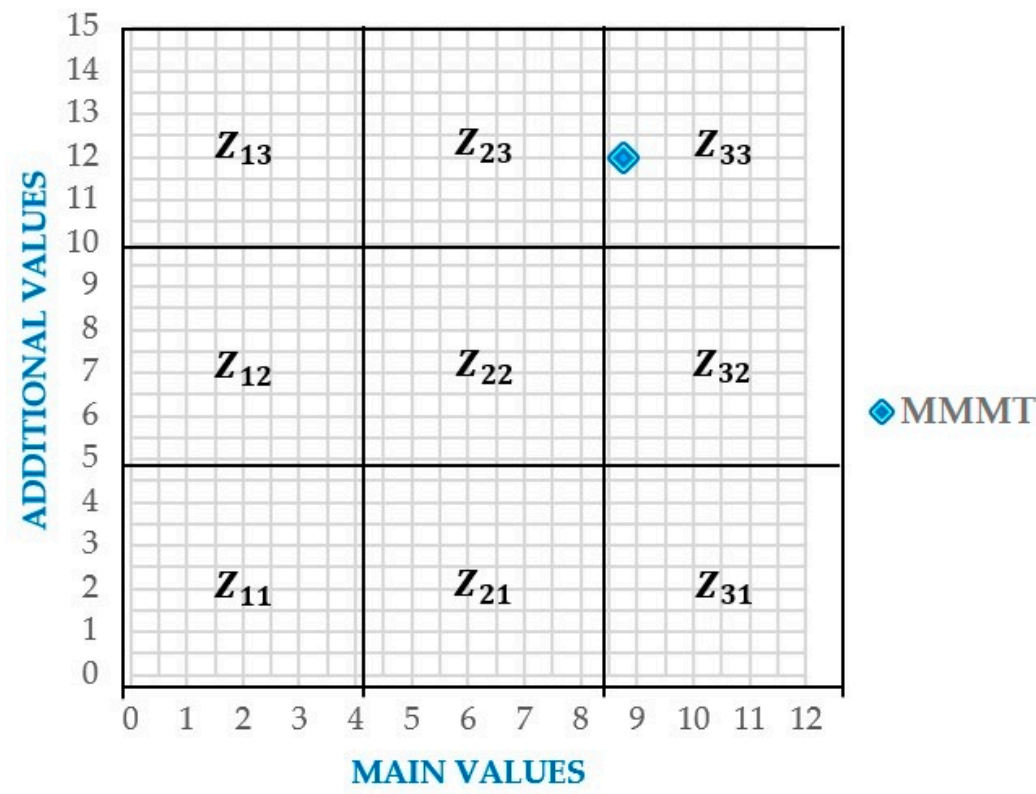

Figure 5. MMMT's position as a result of the GAM evaluation.

MMMT's assessment by the Brilha method showed high results for the scientific $(330 / 400)$, touristic $(365 / 400)$ and educational $(380 / 400)$ value. In addition, the applied method highlights the high representativeness, the uniqueness and the associations with the natural, cultural and historical value of the museum (Table 5). These characteristics reflect a high educational level for all types of tourist. 
Table 4. Evaluation score for each indicator of the main or additional value of the GAM, applied to the MMMT.

\begin{tabular}{|c|c|c|c|}
\hline \multicolumn{4}{|c|}{ Geosite Assessment Model (GAM) } \\
\hline Values & Indicators & Subindicators & Score \\
\hline \multirow{15}{*}{ Main Values } & \multirow{5}{*}{$\begin{array}{c}\text { Scientific/Educational } \\
\text { values (VSE) }\end{array}$} & Rarity & 0.50 \\
\hline & & Representativeness & 0.75 \\
\hline & & Knowledge of geoscientific issues & 1.00 \\
\hline & & Level of interpretation & 1.00 \\
\hline & & (VSE) Total & 3.25 \\
\hline & \multirow{5}{*}{$\begin{array}{l}\text { Scenic/Aesthetic } \\
\text { values (VSA) }\end{array}$} & Viewpoints & 0.75 \\
\hline & & Surface & 0 \\
\hline & & Surrounding landscape and nature & 1.00 \\
\hline & & Environmental fitting of sites & 1.00 \\
\hline & & (VSA) Total & 2.75 \\
\hline & \multirow{5}{*}{ Protection (VPr) } & Current condition & 1.00 \\
\hline & & Protection level & 0.75 \\
\hline & & Vulnerability & 0.50 \\
\hline & & Suitable number of visitors & 0.50 \\
\hline & & (VPr) Total & 2.75 \\
\hline \multirow{17}{*}{ Additional Values } & \multirow{7}{*}{ Functional values (VFn) } & Current condition & 1.00 \\
\hline & & Protection level & 1.00 \\
\hline & & Vulnerability & 0.75 \\
\hline & & Suitable number of visitors & 1.00 \\
\hline & & Current condition & 0.75 \\
\hline & & Protection level & 0.75 \\
\hline & & (VFn) Total & 5.25 \\
\hline & \multirow{10}{*}{ Touristic values (VTr) } & Promotion & 0.75 \\
\hline & & Organised visits & 1.00 \\
\hline & & Vicinity of visitors center & 1.00 \\
\hline & & Interpretative panels & 0.50 \\
\hline & & Number of visitors & 0.25 \\
\hline & & Tourism infrastructure & 0.50 \\
\hline & & Tour guide service & 0.75 \\
\hline & & Hostelry service & 1.00 \\
\hline & & Restaurant service & 1.00 \\
\hline & & (VTr) Total & 6.75 \\
\hline
\end{tabular}

Table 5. Indicators used for the quantitative assessment of the MMMT by the Brilha method.

\begin{tabular}{|c|c|c|c|}
\hline Indicators/Subindicators & \multirow{2}{*}{ Values } & \multirow{2}{*}{\multicolumn{2}{|c|}{ Weight }} \\
\hline Scientific Value (SV) & & & \\
\hline Representativeness & 4 & \multicolumn{2}{|c|}{120} \\
\hline Key locality & 2 & \multicolumn{2}{|c|}{40} \\
\hline Scientific knowledge & 4 & \multicolumn{2}{|c|}{20} \\
\hline Integrity & 4 & \multicolumn{2}{|c|}{60} \\
\hline Geological diversity & 4 & \multicolumn{2}{|c|}{20} \\
\hline Rarity & 4 & \multicolumn{2}{|c|}{60} \\
\hline Use limitations & 1 & \multicolumn{2}{|c|}{10} \\
\hline (SV) Total & & \multicolumn{2}{|c|}{330} \\
\hline $\begin{array}{l}\text { Potential Educational Use (PEU) and Potential Tourism } \\
\text { Use (PTU) }\end{array}$ & Values & \multicolumn{2}{|c|}{ Weight } \\
\hline PTU & & PEU & PTU \\
\hline Vulnerability & 3 & 30 & 30 \\
\hline Accessibility & 4 & 40 & 40 \\
\hline Use limitations & 4 & 20 & 20 \\
\hline
\end{tabular}


Table 5. Cont.

\begin{tabular}{|c|c|c|c|}
\hline $\begin{array}{c}\text { Potential Educational Use (PEU) and Potential Tourism } \\
\text { Use (PTU) }\end{array}$ & Values & \multicolumn{2}{|c|}{ Weight } \\
\hline Safety & 4 & 40 & 40 \\
\hline Logistics & 4 & 20 & 20 \\
\hline Density of population & 2 & 10 & 10 \\
\hline Association with other values & 4 & 20 & 20 \\
\hline Scenary & 4 & 20 & 60 \\
\hline Uniqueness & 4 & 20 & 40 \\
\hline Observation conditions & 4 & 40 & 20 \\
\hline Interpretative potential & 4 & 80 & 40 \\
\hline Geological diversity & 4 & 40 & 5 \\
\hline Geological diversity & 4 & & 20 \\
\hline Total & & 380 & 365 \\
\hline Degradation Risk (DR) & Values & \multicolumn{2}{|c|}{ Weight } \\
\hline Deterioration of geological elements & 2 & \multicolumn{2}{|c|}{70} \\
\hline $\begin{array}{l}\text { Proximity to areas/activities with potential to } \\
\text { cause degradation }\end{array}$ & 2 & \multicolumn{2}{|c|}{40} \\
\hline Legal protección & 1 & \multicolumn{2}{|c|}{20} \\
\hline Accessibility & 4 & \multicolumn{2}{|c|}{60} \\
\hline Density of population & 2 & \multicolumn{2}{|c|}{20} \\
\hline Total & & \multicolumn{2}{|c|}{210} \\
\hline
\end{tabular}

The degradation risk (210/400) (Table 5) presents the museum as a vulnerable geosite in the face of insufficient legal protection and proximity to degrading activities. Based on the overall result, the MMMT is classified as moderately at risk according to Table 3.

\subsection{Delphi Method Results}

The results obtained indicate the MMMT as an ex-situ geosite of high geological importance, preserving minerals and rocks collections typical of the Zaruma-Portovelo mining district. In addition, within its collections, the museum exhibits old equipment used by mining companies that started artisanal gold extraction. However, the museum is susceptible to degrading factors such as weather, certain factors of the terrain and illegal exploitation of its surroundings. Furthermore, the evaluators exposed limitations in the services and structure of the museum, mainly as to the signage in the nearby area (Figure 6).

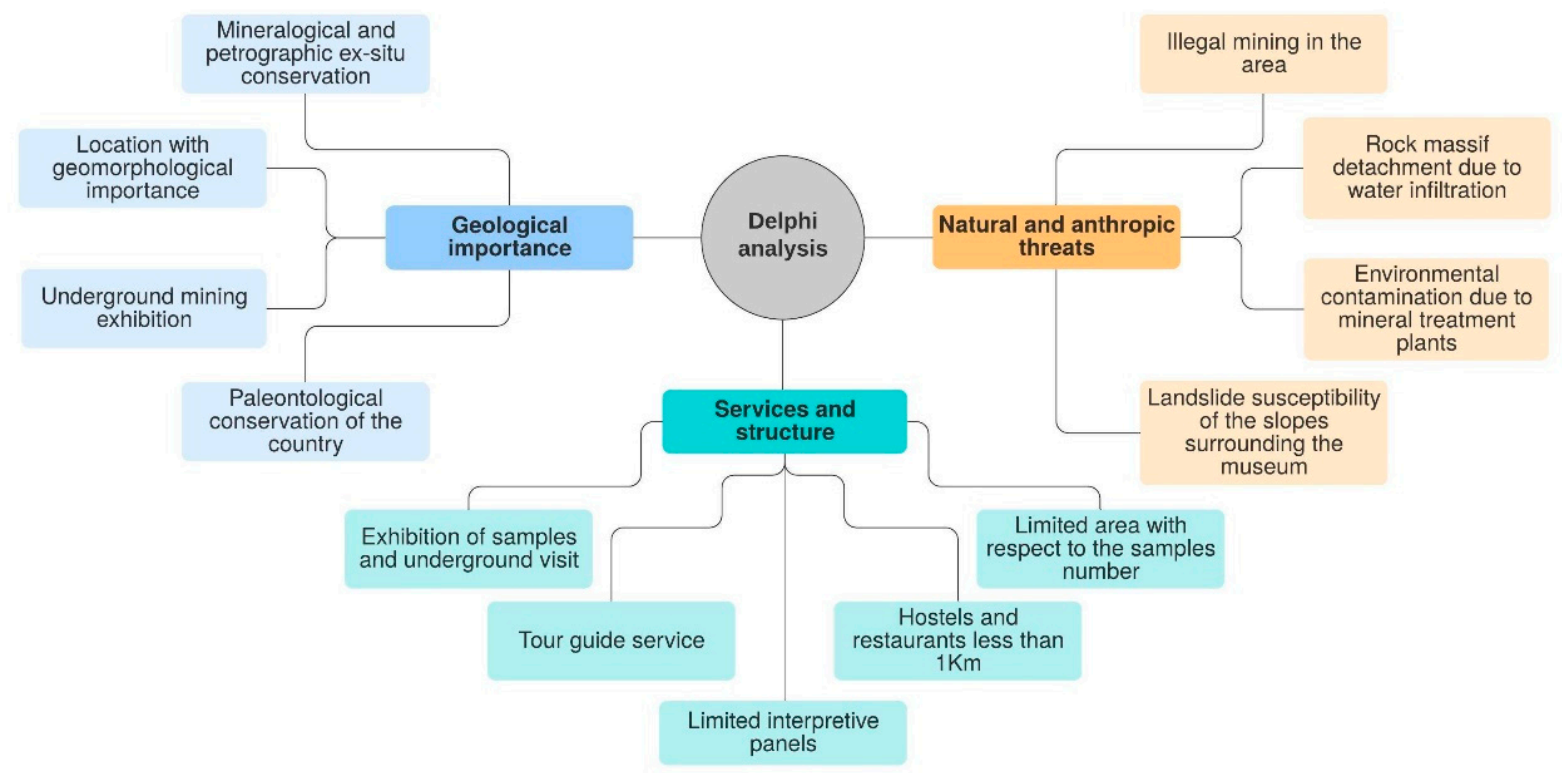

Figure 6. A summary scheme of the Delphi method's results. 


\subsection{The SWOT Matrix}

Based on SWOT analysis, the MMMT is a site of unique geological interest, located in an area with scenic beauty, rich culture and a history of artisanal mining. The importance of MMMT's geoconservation represents opportunities for tourism development in the Ruta del Oro Geopark project. In addition, within the analysis, the needs for geoconservation laws and dissemination strategies were mainly raised to ensure the site's integrity and increase its tourist influx, respectively. The summary of the analysis carried out is presented in Table 6.

Table 6. Strengths, weaknesses, opportunities and threats (SWOT) matrix of the MMMT.

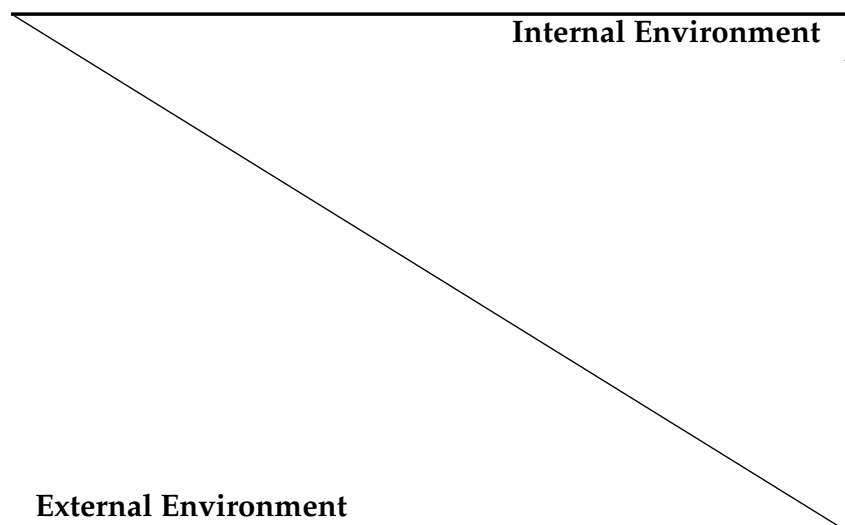

Opportunities

Strengths
1. Recognised in the Ecuadorian
Museum Network.
2. Main routes in good condition,
connected to the city.
3. It has around seven thousand
samples from different parts of
the world.
4. It symbolises artisanal mining
with its underground mines.
5. It has samples of the area, the
country and the world.

a. Develop the museum as an opportunity for alliances that promote tourism and exceptional geological beauty. b. Promote the geosite as a geological heritage of international value within the Ruta del Oro Geopark project

c. Create interdisciplinary programs for the new generations and participation in exhibition programs at open house exhibitions.

d. Manage jobs for highly qualified professionals in museum studies.

e. New openings for volunteers and interns with fieldwork initiatives.

f. Provide experiences through the digital age for greater diffusion of the site and increased visitors.

\section{Threats}

a. Deterioration and risks in the face of natural events b. Cultural trend: devaluation due to the lack of interest in knowledge of the new generations.

c. Due to the current virtual age, an ageing population could reduce potential visitors.

d. Regulations that affect the tourism sector.

f. Mineral treatment plants near the geosite that pollute the environment. 1.2.b.d.e. Manage a tourism development plan.

3.b.c.e. Integrate technology into the scientific, cultural and/or educational dissemination plan. 4.a.b. Promote geosite conservation through the geopark approach. 5.a.c.f. Implement digital instruments for tourism promotion. + Opportunities

1. Limited academic and government alliances. 2. Limited government funding or resources and competition between franchises.

3. Lacking of educational and scientific publications.

4. Low TIC index (Technology,

Information and

Communication) in all its areas.

5. Lacking of a property inventory.

\section{Strategies: Weaknesses}

+ Opportunities

1.a.b.c. Create financing mechanisms with public and private sector institutions and universities.

2.5.a.b. Improve tourist infrastructures through state support and informative activities such as routes, panels, guides, and catalogues. 4.d.e. Develop interdisciplinary programs to promote local economic development. 4.5.c.e. Employ the use of new digital technologies through mobile applications or geocaching.

\section{Strategies: Weaknesses-Threats}

1.4.c.d. Inform the community about geotourism and tourism promotion under a sustainable approach. 5.b.d.e. Implement legal regulations and standards that promote geoconservation. 5.c.d. Identify the geological heritage potential with professional experience help. 3.5.c.d. Ensure the preservation of the assets of the museum through plans that protect its legacy to future generations. 3.4.d.e. Close mining or other activities that imply interest site degradation.

\section{Interpretation of Results and Discussion}

The evaluation methodology used allowed us to expose the main characteristics of the MMMT and its importance within the geological and mining heritage of the ZarumaPortovelo district. Moreover, it made it possible to determine the weaknesses that should 
be enhanced and improved for tourism. According to [43], the MMMT corresponds to the second most valued geosite $(256 / 400)$ of a total of 27 geosites and mining sites present in the study area. In one study, the IELIG method was applied [71]. In this study, the Brilha [1] and GAM [64] methods were applied, two classic methodologies for evaluating the scientific, academic and touristic interest of possible geosites. The results obtained through Brilha and GAM are similar to those obtained in the evaluation of [43] by the IELIG method. The high values obtained for both evaluation methods (Tables 4 and 5) qualify the museum as an excellent example of an ex-site geosite.

The evaluation carried out by GAM generally qualifies the museum as a geosite with high principal and additional value (Table 4). However, it reflects subindicators with poor scores that need to be strengthened (e.g., vulnerability, area, structure and tourist influx). Although the museum occupies $90 \%$ of the structure, the number of samples limits the capacity of tourists (maximum 20 people). This problem translates into an average tourist influx of fewer than 5000 people per year.

The Brilha method presents high results for the museum's scientific, educational and touristic value (Table 5). These values classify the MMMT as a geosite of much geological importance, and the best example in the study area to show the geology of the area and the processes related to pre-colonial gold extraction. The geological elements are informative to all types of patrons. In addition to its geological importance, the MMMT has historical, cultural and ecological value that increases its potential for geotourism in the area.

Regarding the degradation risk evaluation (DR), the museum presents a medium risk of degradation in the face of natural and anthropic processes (Table 5). Its main weaknesses lie in its proximity to degrading activities (e.g., illegal mining and contamination from mineral processing plants) and the lack of laws that protect geological heritage conservation areas. The limited area of the museum is a factor that influences the possible deterioration of secondary geological elements by the tourist. Due to its location, an essential factor is the economic level of the population. The area stands out for its limited economic resources that disadvantage the services offered to tourists and the implementation of new geoconservation techniques.

The subjectivity of geosite assessment methods is unavoidable. However, it is possible to decrease it. According to [72], the application of several methods generates different results so that their combination allows obtaining a better result and eliminating subjectivity to a certain degree. In addition, it is essential to have: (i) a team of evaluators with knowledge on the subject and (ii) information on the geosite in which the inhabitants and tourists are involved [73]. The participation of people outside the geoscientific field validates the evaluations, reduces subjectivity and improves the acceptance and success of geosite management plans [74].

Based on the above, the study included the museum's Delphi and SWOT analysis. The results revealed the current situation and possible future scenarios, considering their most relevant characteristics. In general, this analysis relates the geotourism potential of the museum to the natural, cultural and historical heritage as a fundamental part of the Ruta del Oro Geopark project and the area's tourism development. An important aspect of the SWOT analysis was the lack of recognition of the touristic potential of the site by government authorities. This translates into a lack of financial and promotional support for the museum.

Finally, to ameliorate the MMMT's weaknesses, a proposal is presented that includes various specific strategies (based on SWOT and the other applied analyses) that seek to improve the structure and services offered by the museum:

- To increase the museum's area vertically (add one or two floors) and facilitate access for people with disabilities or mobility restrictions.

- To implement a digital and physical classification system, with files identified by codes, to facilitate orderly and chronological recording of the museum's assets.

- To design a museum web page containing pertinent information on the distribution of the sections and samples, focused on scientific, educational and cultural diffusion. 
- To improve the in-situ mines through strategic viewpoints to observe alteration zones, mineralisation or old mining equipment, so that tourists can understand the artisanal extraction process.

- To establish learning workshops for visitors: a gold-panning area (Figure 7a), interpretation of cartography (Figure 7b), identification of minerals (Figure 7c), stereoscopic visualisation of aerial photography and mineral observation under a microscope (Figure 7).

- To establish regulations and legal norms with the help of municipalities whose objective is to conserve the museum; closing down all types of illegal mining activity in its surroundings.

- To improve the museum's signage system, with names for each exhibition room and information panels.

- $\quad$ To prepare the main access roads and establish an area designated as a tourist parking lot, with a capacity of at least eight vehicles.

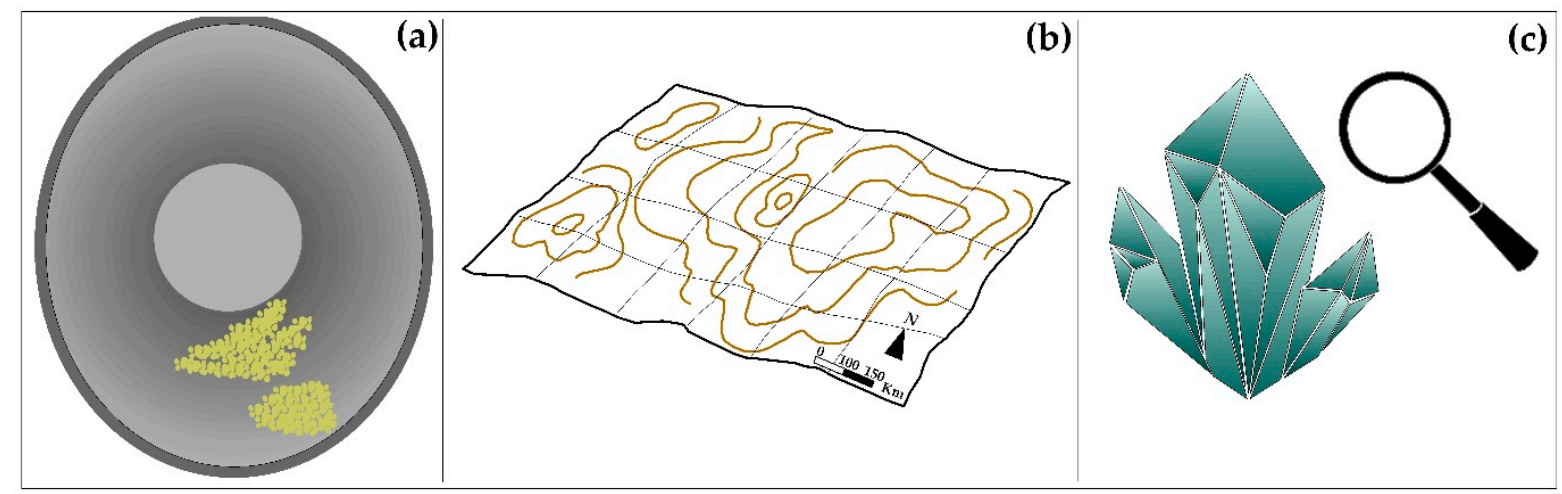

Figure 7. Proposed activities for tourists: (a) a gold-panning area, (b) cartographic interpretation and (c) identification of minerals.

In general, the way we addressed our case study addressed can be used as a model for museums in regions where there are mineral deposits. An improvement on the approach proposed in this study could be the inclusion of other sites for collective analysis and the introduction of other valuation methodologies.

\section{Conclusions}

The MMMT has high scientific, touristic and educational value. It is an ex-situ geosite with principles oriented toward geoconservation. This geosite combines the geological, historical, cultural and natural wealth of the district. The evaluation carried out allowed us to validate its importance in the context of the Ruta del Oro Geopark project as one of the main points of interest for geotourism in the area. Combining semiquantitative and qualitative methodologies in the study allowed the exchange of criteria of experts and parties interested in the geosite. This methodological proposal decreased the subjectivity of the method and allowed for strategies in contrast to the current conditions presented by the museum.

Our improvement strategies focus on three main aspects: (i) enlargement of the area and improvement of services offered; (ii) promoting the creation of legal regulations that protect geosites from the risks linked to anthropic activities; and (iii) modern dissemination and promotion techniques at the national and international levels. Provided the proposals made in this study are realised, the museum will increase its tourist influx, contributing positively to the area's economic development.

From a technical/scientific point of view, we can reinforce the MMMT's value as a repertoire of the mineral diversity of the area and a point of interest for research. Additionally, we have revealed the limited support of regional authorities in the MMMT's 
development; even so, private impulses and social support, in general, have allowed the development of the museum.

Supplementary Materials: The following are available online at https://www.mdpi.com/article/ 10.3390/min11060582/s1. Figure S1: External services of the museum; $(a, b)$ Underground mines. Figure S2: Mineralogical and petrographic collection: (a) desert rose, (b) pyrite, (c) quartz, (d) amethyst. Figure S3: Paleontological units: (a) ammonite and (b) gastropod footprint. Figure S4: (a) Artisanal mining equipment and (b) archaeological pieces.

Author Contributions: Conceptualisation, P.C.-M., F.M.-C. and M.A.-A.; methodology, P.C.-M., F.M.C., M.A.-A. and E.B.; validation, P.C.-M., F.M.-C. and M.T.-C.; investigation, P.C.-M., I.T.-S. and K.Z.-R.; data curation, M.A.-A. and K.Z.-R.; writing—original draft preparation, M.T.-C., P.C.-M. and F.M.-C.; writing-review and editing, M.A.-A., E.B., P.C.-M., F.M.-C. and K.Z.-R.; visualisation, M.A.-A., K.Z.-R. and I.T.-S.; supervision, M.T.-C., P.C.-M., F.M.-C. and E.B. All authors have read and agreed to the published version of the manuscript.

Funding: This research was funded by ESPOL Polytechnic University research projects: “Registry of geological and mining heritage and its impact on the defense and preservation of geodiversity in Ecuador", CIPAT-01-2018; and "Propuesta de Geoparque Ruta del Oro y su incidencia en el desarrollo territorial", CIPAT-02-2018.

Data Availability Statement: The data presented in this study are available in article and Supplementary Material.

Acknowledgments: This work is based on previous initiatives sponsored by the Red Minería XXI (CYTED: 407310RT0402, IGME). Furthermore, we thank the reviewers and editorial committee for their observations and suggestions for improving the manuscript.

Conflicts of Interest: The authors declare no conflict of interest.

\section{References}

1. Brilha, J. Inventory and Quantitative Assessment of Geosites and Geodiversity Sites: A Review. Geoheritage 2016, 8, 119-134. [CrossRef]

2. Gray, M.; Gordon, J.E.; Brown, E.J. Geodiversity and the ecosystem approach: The contribution of geoscience in delivering integrated environmental management. Proc. Geol. Assoc. 2013, 124, 659-673. [CrossRef]

3. Nieto, L.M. Geodiversidad: Propuesta de una definición integradora. Boletín Geológico Min. 2001, 112, 3-112.

4. Carcavilla, L.; Martínez, J.L.; Valsero, J.D. Patrimonio Geológico y Geodiversidad: Investigación, Conservación, Gestión y Relación con los Espacios Naturales Protegidos; Instituto Geológico y Minero de España: Madrid, Spain, 2007; Volume 7.

5. Cendrero, A. El patrimonio geológico. Ideas para su protección, conservación y utilización. In El Patrimonio Geológico. Bases para su Valoración, Protección, Conservación y Utilización; Ministerios de Obras Públicas Transporte y Medio Ambiente: Madrid, Spain, 1996; pp. 17-27.

6. Gallego, E.; Cortés, A.G. El Patrimonio Geológico. Ideas para su Protección, Conservación y Utilización; Ministerio de Obras Públicas, Transportes y Medio Ambiente: Madrid, Spain, 1996.

7. Lago, M.; Arranz, E.; Andrés, J.A.; Soria, A.R.; Galé, C. Patrimonio Geológico: Bases para su estudio y Metodología; Publicaciones del Consejo de Protección de la Naturaleza de Aragón. Serie Investigación: Zaragoza, Spain, 2001; p. 107.

8. Alarcón, J.C.B. Propuesta de Estrategia Andaluza para la Conservación de la Geodiversidad. Junta de Andalucía; Consejería de Medio Ambiente: Andalucía, Spain, 2002; p. 103.

9. Mercado, M. Patrimonio Geológico de Colombia: Una propuesta preliminar para su inventario. In Proceedings of the III International Symposium ProGEO on the Conservation of the Geological Heritage, Zaragoza, Spain, 23-25 November 1999; p. 13.

10. Durán, J.J. El patrimonio geológico de España: Situación actual y perspectivas de futuro. In Proceedings of the I Simposium Transfronterizo sobre Patrimonio Natural; Mata-Perelló, J.M., Serra, J., Eds.; Sociedad Española para la defensa del Patrimonio Geológico y Minero: Lleida, Spain, 1999; pp. 7-20.

11. Newsome, D.; Dowling, R. Geoheritage and Geotourism. In Geoheritage: Assessment, Protection, and Management; Reynard, E., Brilha, J., Eds.; Elsevier: Amsterdam, The Netherlands, 2018; pp. 305-321.

12. Brilha, J. Geoheritage and Geoparks. In Geoheritage: Assessment, Protection, and Management; Reynard, E., José, B., Eds.; Elsevier: Amsterdam, The Netherlands, 2018; pp. 323-335.

13. Larwood, J.; Prosser, C. Geotourism, Conservation and Society Earth heritage conservation in the UK-Its status Conservation and geotourism-Some examples from the UK. Geol. Balc. 1998, 28, 97-100.

14. Hose, T.A. The English Origins of Geotourism (as a Vehicle for Geoconservation) and Their Relevance to Current Studies. Acta Geogr. Slov. 2011, 51, 343-359. [CrossRef] 
15. Herrera-Franco, G.; Montalván-Burbano, N.; Carrión-Mero, P.; Apolo-Masache, B.; Jaya-Montalvo, M. Research Trends in Geotourism: A Bibliometric Analysis Using the Scopus Database. Geosciences 2020, 10, 379. [CrossRef]

16. Frey, M.L. Geologie-Geo-Tourismus-Umweltbildung: Themen und Tätigkeitsbereiche im Spannungsfeld Ökonomie und Nachhaltige Entwicklung-Terra Nostra. Schriften der Alfred-Wegener Stift. 1998, 98, V85.

17. Newsome, D.; Dowling, R.K. Setting an agenda for geotourism. In Geotourism: The Tourism of Geology and Landscape; Newsome, D., Dowling, R.K., Eds.; Goodfellow Publishers Limited: Wallingford, UK, 2010; pp. 1-12.

18. Hose, T.A.; Vasiljević, D.A. Defining the Nature and Purpose of Modern Geotourism with Particular Reference to the United Kingdom and South-East Europe. Geoheritage 2012, 4, 25-43. [CrossRef]

19. Dowling, R.K. Global Geotourism-An Emerging Form of Sustainable Tourism. Czech. J. Tour. 2014, 2, 59-79. [CrossRef]

20. Hose, T.A. Geoheritage and Geotourism: A European Perspective; Boydell \& Brewer: Woodbridge, UK, 2016.

21. Słomka, T.; Kicińska-Świderska, A. The basic concepts of geotourism. Geoturystyka/Geotourism 2004, 1, 5-7.

22. Joyce, E. Geological heritage of Australia: Selecting the best for Geosites and World Heritage, and telling the story for geotourism and Geoparks. ASEG Ext. Abstr. 2006, 1, 1-4. [CrossRef]

23. Newsome, D.; Dowling, R.K. The future of geotourism where to from here. In Geotourism: The Tourism of Geology and Landscape; Newsome, D., Dowling, R.K., Eds.; Goodfellow Publishers Limited: Wallingford, UK, 2010.

24. Palacio-Prieto, J.L. Geosites, geomorphosites and geoparks: Importance, actual situation and perspectives in Mexico. Investig. Geográficas 2013, 2013, 24-37. [CrossRef]

25. Jakubowski, K.J. Geological Heritage and Museums. In Proceedings of the Geological Heritage Concept, Conservation and Protection Policy in Central Europe, Cracow, Poland, 3-4 October 2003; Volume 13, pp. 21-28.

26. Nudds, J.R.; Pettitt, C.W. (Eds.) International Accord on the Value of Natural Science Collection. In Proceedings of the the Value and Valuation of Natural Science Collections: Proceedings of the International Conference, Manchester, UK, 19-21 April 1995; Geol. Soc.: Manchester/London, UK, 1995; pp. 211-214.

27. Mariotto, F.P.; Venturini, C. Strategies and Tools for Improving Earth Science Education and Popularization in Museums. Geoheritage 2017, 9, 187-194. [CrossRef]

28. Desvallées, A.; Mairesse, F. (Eds.) Key Concepts of Museology; Armand Colin: Paris, France, 2010.

29. Pop, D.; Horák, J.; Hurlbut, J. Mineral Museums as Alliance Partners in Teaching Mineral Sciences. J. Geosci. Educ. 2004, 52, 87-96. [CrossRef]

30. Martini, G. Geological heritage and geo-tourism. In Geological Heritage: Its Conservation and Management; Barettino, D., Wimbledon, W.A.P., Gallego, E., Eds.; Ministerios de Ciencia y Tecnología: Madrid, Spain, 2000; pp. 147-156.

31. Pérez-Lorente, F. Experiences of geoconservation in La Rioja (Spain). In Geological Heritage: Its Conservation and Management; Barettino, D., Wimbledon, W.A.P., Gallego, E., Eds.; Ministerios de Ciencia y Tecnología: Madrid, Spain, 2000; pp. 165-183.

32. Gervais, A.; Gervais, K. The protective hall over the natural monument "The Muenchehagen dinosaurs tracks" and the museum's educational concept. In Towards the Balanced Management and Conservation of the Geological Heritage in the New Millenium; Barettino, D., Vallejo, M., Gallego, E., Eds.; Instituto Tecnológico GeoMinero de España: Madrid, Spain, 1999; pp. $319-323$.

33. De Carvalho, A.G. Exomuseum of Geology. In Towards the Balanced Management and Conservation of the Geological Heritage in the New Millenium; Barettino, D., Vallejo, M., Gallego, E., Eds.; Instituto Tecnológico GeoMinero de España: Madrid, Spain, 1999; pp. 406-409.

34. Carrión-Mero, P.; Loor-Oporto, O.; Andrade-Ríos, H.; Herrera-Franco, G.; Morante-Carballo, F.; Jaya-Montalvo, M.; AguilarAguilar, M.; Torres-Peña, K.; Berrezueta, E. Quantitative and Qualitative Assessment of the "El Sexmo" Tourist Gold Mine (Zaruma, Ecuador) as A Geosite and Mining Site. Resources 2020, 9, 28. [CrossRef]

35. Massarani, L.; León-Castella, A.; Aguirre, C.; Reynoso, E.; Lindegaard, L.; Fernandez, E. Guía de Centros y Museos de Ciencia de América Latina y El Caribe; UNESCO: Montevideo, Uruguay, 2015.

36. Instituto Geológico y Minero de España (IGME). Museo Geominero; Instituto Geológico y Minero de España (IGME): Madrid, Spain, 2016.

37. TEA; AECOM. TEA/AECOM 2019. Theme Index and Museum Index: The Global Attractions Attendance Report; Rubin, J., Ed.; Themed Entertainment Association (TEA): Burbank, CA, USA, 2019.

38. Gouveia, F.; Kurtenbach, E. Mapping the web relations of science centres and museums from Latin America. Scientometrics 2009, 79, 491-505. [CrossRef]

39. Knell, S.J.; MacLeod, S.; Watson, S. (Eds.) Museum Revolutions: How Museums Change and are Changed; Taylor \& Francis e-Library: New York, NY, USA, 2007.

40. Instituto Nacional de Patrimonio Cultural (INPC). Instructivo para Fichas de Registro e Inventario de Bienes Muebles; Noboa, E., Ed.; Ediecuatorial: Quito, Ecuador, 2011.

41. Charvet, E.S. Políticas para una Revolución Cultural; Ministerio de Cultura del Ecuador: Quito, Ecuador, 2011 ; Volume 44.

42. Carrión, P.; Ramos, V.; Peralta, M. Museo geominero Magner Turner. In El Patrimonio Geominero en el Contexto de la Ordenación Territorial; Martins, L., Carrión, P., Eds.; Imprenta Mistral: Guayaquil, Ecuador, 2005; p. 467.

43. Mero, P.C.; Franco, G.F.; Briones, J.; Caldevilla, P.; Domínguez-Cuesta, M.J.; Berrezueta, E. Geotourism and local development based on geological and mining sites utilization, Zaruma-Portovelo, Ecuador. Geosciences 2018, 8, 205. [CrossRef]

44. Calle, J. Geología regional de Zaruma-Portovelo y consideraciones ambientales del sector. In El Patrimonio Geominero en el Contexto de la Ordenación del Territorio; Martins, L., Carrión, P., Eds.; ESPOL: Guayaquil, Ecuador, 2005; pp. 307-320. 
45. Carrión-Mero, P.; Herrera-Narváez, G.; Herrera-Franco, G.; Sánchez-Zambrano, E.; Mata-Perelló, J.; Berrezueta, E. Assessment and promotion of geotouristic and geomining routes as a basis for local development: A case study. Minerals 2021, 11, 351. [CrossRef]

46. Sauer, W. Geología del Ecuador; Editorial Talleres Gráficos del Ministerio de Educación: Quito, Ecuador, 1965.

47. Zarroca, M.; Linares, R.; Velásquez-lópez, P.C.; Roqué, C.; Rodríguez, R. Application of electrical resistivity imaging (ERI) to a tailings dam project for artisanal and small-scale gold mining in Zaruma-Portovelo, Ecuador. J. Appl. Geophys. 2015, 113, 103-113. [CrossRef]

48. Oliva, A.; Ruíz, A.; Gallardo, R. Terrain instability in areas of mining activity: Cse Zaruma city, Ecuador. Rev. Redes Ing. 2017, 8, 69-81.

49. Jácome, M.C.; Martinez-Graña, A.M.; Valdés, V. Detection of terrain deformations using InSAR techniques in relation to results on terrain subsidence (Ciudad de Zaruma, Ecuador). Remote Sens. 2020, 12, 1598. [CrossRef]

50. Berrezueta, E.; Ordóñez-Casado, B.; Bonilla, W.; Banda, R.; Castroviejo, R.; Carrión, P.; Puglla, S. Ore petrography using optical image analysis: Application to zaruma-portovelo deposit (Ecuador). Geosciences 2016, 6, 30. [CrossRef]

51. Wolf, T. Geografía y Geología del Ecuador; F. A. Brockhaus: Leipzig, Germany, 1892.

52. Spencer, R.M.; Montenegro, J.L.; Gaibor, A.; Perez, E.P.; Mantilla, G.; Viera, F.; Spencer, C.E. The Portovelo-Zaruma mining camp, SW Ecuador: Porphyry and epithermal environments. SEG Newsl. 2002, 49, 8-14.

53. Bonilla, W. Metalogenia del Distrito Minero Zaruma-Portovelo, República del Ecuador. Ph.D. Thesis, Universidad de Buenos Aires, Buenos Aires, Argentina, 2009.

54. Van Thournout, F.; Salemink, J.; Valenzuela, G.; Merlyn, M.; Boven, A.; Muchez, P. Portovelo: A volcanic-hosted epithermal vein-system in Ecuador, South America. Miner. Depos. 1996, 31, 269-276. [CrossRef]

55. Schütte, P.; Chiaradia, M.; Barra, F.; Villagómez, D.; Beate, B. Metallogenic features of Miocene porphyry Cu and porphyry-related mineral deposits in Ecuador revealed by Re-Os, ${ }^{40} \mathrm{Ar} /{ }^{39} \mathrm{Ar}$, and U-Pb geochronology. Miner. Depos. 2012, 47, 383-410. [CrossRef]

56. Chiaradia, M.; Fontboté, L.; Beate, B. Cenozoic continental arc magmatism and associated mineralization in Ecuador. Miner. Depos. 2004, 39, 204-222. [CrossRef]

57. Banda, R.; Vikent'ev, I.V.; Nosik, L.P. Sulfur isotope composition of the Vizcaya and Nicol veins of Portovelo-Zaruma deposit (Ecuador). Dokl. Akad. Nauk 2005, 405, 783-787.

58. Instituto Nacional de Estadística y Censos (INEC). Población Demográfica. Available online: https:/ / www.ecuadorencifras.gob. ec/censo-de-poblacion-y-vivienda/ (accessed on 12 April 2021).

59. Velásquez-López, P.C.; Veiga, M.M.; Hall, K. Mercury balance in amalgamation in artisanal and small-scale gold mining: Identifying strategies for reducing environmental pollution in Portovelo-Zaruma, Ecuador. J. Clean. Prod. 2010, 18, $226-232$. [CrossRef]

60. Murillo, R. Zaruma, Historia Minera: Identidad en Portovelo; Ediciones Abya-Yala: Quito, Ecuador, $2000 ;$ ISBN 9978046208.

61. Oviedo-Achundia, R.; Moina-Quimí, E.; Naranjo-Morán, J.; Barcos-Arias, M. Contaminación por metales pesados en el sur del Ecuador asociada a la actividad minera. Bionatura 2017, 2, 437-441. [CrossRef]

62. Paredes Pozo, D.C. ¿Después de la minería que?: Análisis del Impacto Socioeconómico y Ambiental de la Minería: Caso South American Development Company (SADCO-CIMA), Portovelo y Zaruma-El Oro-Ecuador. Master's Thesis, FLACSO Sede Ecuador, Quito, Ecuador, 2013.

63. Mora, G.; Rodríguez, R. Historia y Actualidad de la Explotación Minera de los Cantones Zaruma y Portovelo; G. Mora: Quito, Ecuador, 2008.

64. Vujičić, M.D.; Vasiljević, D.A.; Marković, S.B.; Hose, T.A.; Lukić, T.; Hadžić, O.; Janićević, S. Preliminary geosite assessment model (GAM) and its application on Fruška gora mountain, potential geotourism destination of Serbia. Acta Geogr. Slov. 2011, 51,361-376. [CrossRef]

65. Mckenna, H.P.; Hons, D.P.M.; Rgn, D.R. The Delphi technique: A worthwhile research approach for nursing? J. Adv. Nurs. 1994, 19, 1221-1225. [CrossRef] [PubMed]

66. Hasson, F.; Keeney, S. Technological Forecasting \& Social Change Enhancing rigour in the Delphi technique research. Technol. Forecast. Soc. Chang. 2011, 78, 1695-1704.

67. Dyson, R.G. Strategic development and SWOT analysis at the University of Warwick. Eur. J. Oper. Res. 2004, 152, 631-640. [CrossRef]

68. Carrión-Mero, P.; Aguilar-Aguilar, M.; Morante-Carballo, F.; Domínguez-Cuesta, M.J.; Sánchez-Padilla, C.; Sánchez-Zambrano, A.; Briones-Bitar, J.; Blanco-Torrens, R.; Córdova-Rizo, J.; Berrezueta, E. Surface and Underground Geomechanical Characterization of an Area Affected by Instability Phenomena in Zaruma Mining Zone (Ecuador). Sustainability 2021, 13, 3272. [CrossRef]

69. Vangsnes, G.F. The meanings of mining: A perspective on the regulation of artisanal and small-scale gold mining in southern Ecuador. Extr. Ind. Soc. 2018, 5, 317-326.

70. Ammirati, L.; Mondillo, N.; Rodas, R.A.; Sellers, C.; Di Martire, D. Monitoring Land Surface Deformation Associated with Gold Artisanal Mining in the Zaruma City (Ecuador). Remote Sens. 2020, 12, 2135. [CrossRef]

71. García-Cortés, Á.; Carcavilla Urquí, L.; Apoita Mugarza, B.; Arribas, A.; Bellido, F.; Barrón, E.; Delvene, G.; Díaz-Martínez, E.; Díez, A.; Durán, J.J.; et al. Documento metodológico para la elaboración del Inventario Español de Lugares de Interés Geológico (IELIG). Propuesta para la actualización Metodológica; Instituto Geológico y Minero de España: Madrid, Spain, 2013; pp. 1-64. 
72. Štrba, L.; Kršák, B.; Sidor, C. Some Comments to Geosite Assessment, Visitors, and Geotourism Sustainability. Sustainability 2018, 10, 2589. [CrossRef]

73. Štrba, L.; Rybár, P.; Baláž, B.; Moloká, M. Current Issues in Tourism Geosite assessments: Comparison of methods and results. Curr. Issues Tour. 2015, 18, 496-510. [CrossRef]

74. Bruschi, V.M.; Cendrero, A. Geosite evaluation; can we measure intangible values? Alp. Mediterr. Quat. 2005, 18, 293-306. 